\title{
Kerjasama Antara Pemerintahan Amerika Serikat Dan Filipina Dalam Memberantas Abu Sayyaf Group Di Filipina Selatan
}

\author{
Aulia AsSakir
}

Universitas Muhammadiyah Yogyakarta

asokfree@live.com

\begin{abstract}
Abstrak
Penelitian ini fokus pada pembahasan serangan teroris terhadap Amerika Serikat pada Gedung World Trade Center (WTC) di New York dan Gedung Pentagon di Washington pada 11 September 2001 (9/11). Dimana pelaku tragedi 9/11 adalah jaringan terorisme Al-Qaeda yang pernah dipimpin oleh Osama bin Laden. Serangan tersebut jugapunya afiliasi dengan kelompok Abu Sayyaf Group. Abu Sayyaf Group merupakan sebuah kelompok militan yang beroperasi di Filipina Selatan dan mempromosikan pendirian sebagai suatu negara Islam yang merdeka di Mindanao dan Kepulauan Sulu, Filipina Selatan. Abu Sayyaf Group terlibat dalam berbagai tindak kekerasan, seperti pemboman, pembunuhan, penculikan dan penyanderaan maupun pemerasan.

Dalam perkembangannya, Abu Sayyaf Group berpotensi mengancam keamanan nasional Amerika Serikat dan Filipina serta membutuhkan penanganan dengan respons yang sama, yakni militer dalam menghadapinya. Dalam membendung ancaman Abu Sayyaf Group, kedua negara ini sepakat untuk menjalin kerjasama. Maka, Amerika Serikat dan Filipina melaksanakan kerjasama di bidang militer melalui pelaksanaan latihan militer gabungan antara kedua pasukan yang dilaksanakan pada tahun 2002 tempatnya di Kepulauan Basilan, Filipina Selatan. Penelitian ini bertujuan untuk menunjukkan keberhasilan maupun kegagalam dalam penerapan kerjasama antara Amerika Serikat dan Filipina. Hal ini yang akhirnya mendapat dukungan publik dan politik domestik pada kerjasama Amerika Serikat dan Filipina yang dilengkapi dengan program pemerintahan Filipina dalam reformasi sosial dan peningkatan ekonomi di Pulau Basilan tempat
\end{abstract}


wilayah Abu Sayyaf Group beroperasi.

Kata Kunci: Tragedi 9/11, Berantas, Ancaman, Keamanan, Kerjasama, Militer, Abu Sayyaf Group.

\begin{abstract}
This study focuseson the discussionterrorist attacks against the United States at the World Trade Center Building in New York and the Pentagon Building in Washington on September 11, 2001 (9/11). Where the tragedy of 9/11 is Al-Qaeda terrorist network that once led by Osama bin Laden. And has links with the Abu Sayyaf Group. The Abu Sayyaf Group is a militant group operating in the Southern Philippines and promotes the establishment as an independent Islamic state in Mindanao and the Sulu Islands of the southern Philippines. The Abu Sayyaf Group is involved in various acts of violence, such as bombings, killings, kidnappings and hostage-taking as well as extortion.

In its development, the Abu Sayyaf Group may threaten the national security of the United States and the Philippines that are military or armed threats and require a military response in the face of it. To face the threat of Abu Sayyaf Group, the two countries agreed to establish cooperation. In an attempt to confront military threats or other armed threats coming from the Abu Sayyaf Group. Thus, the United States and the Philippines undertook military cooperation through joint military exercises between the two forces held in 2002 in the Basilan Islands of the southern Philippines. This study aims to show the success and kegagalam in the application of cooperation between the United States and the Philippines. This ultimately gained public and domestic political support for US and Philippine cooperation complemented by the Philippine government's program of social reform and economic improvement on Basilan Island where the Abu Sayyaf Group operates.
\end{abstract}

Keywords: Tragedy 9/11, Eradicate, Threats, Security, Cooperation, Military, Abu Sayyaf Group.

Latar Belakang Masalah

Penelitian ini fokus pada pem- bahasan serangan teroris terhadap Amerika Serikat dalam Tragedi 11 
September tahun 2001 (9/11), yang telah menghancurkan Gedung World Trade Center di New York dan Gedung Pentagon di Washington. Kedua gedung tersebut merupakan sebagai simbol kekuatan militer Amerika Serikat, ${ }^{1}$ Amerika Serikat dalam konteks ini merupakan korban terorisme internasional. Tragedi 9/11, telah menimbulkan trauma psikologis bagi warga negara Amerika Serikat danmenjadi pembahasan intens yang pada akhirnya menimbulkan pertanyaan mendasar, bagaimana tragedi itu dapat terjadi di negaranya? Oleh karena itu peristiwa ini menuntut kebijakan pemerintah untuk lebih aktif dan harus ada garansi bahwa peristiwa ini tidak akan terulang kembali lagi. Dimana pelaku peristiwa tersebut adalah jaringan terorisme Al-Qaeda yang pernah dipimpinan oleh Osama bin Laden. ${ }^{2}$

Adirini Pujayanti, "Kebijakan Luar Negeri Pemerintahan Bush Terhadap Terorisme Internasionala". Dalam Poltak Pargi Nainggilan, Terorisme, Human Security, Keamanan Internasional dan Tata Dunia Pasca Perang Dingin, Terorisme dan Tata Dunia Baru, Jakarta: Pusat Pengkajian dan Pelayanan Infomasi Sekretariat Jenderal Dewan Perwakilan Rakyat Republik Indonesia, hal.161, 2002

2 Briscoe, C.H. "Balikatan exercise spearheaded ARSOF operations in the Philippines." Special Warfare,Sept.2004,elibraryusa.state.
Dan memiliki keterkaitan dengan kelompok Abu Sayyaf Group di Filipina Selatan yang berlokasi di Kepulauan Sulu dan Mindanao.

Tragedi 9/11 merupakan acaman bagi keamanan Amerika Serikat, karena adanya ancaman bagi keamanan negaranya, presiden George Walker Bush (Bush) mengeluarkan National Security Strategy (NSS) tahun 2002, ${ }^{3}$ atau "war on terrorisme", dimana Amerika Serikat mengajak sejumlah negara-negara di dunia untuk memerangi terorisme demi kepentingan keamanan global bersama. Salah satu negara yang diajak untuk melakukan kerjasama dalam memerangi terorisme adalah Filipina. Filipina merupakan salah satu negara kawasan Asia Tenggara yang dijadikan oleh Amerika Serikat dalam memerangi terorisme, karena di negara Filipina terdapat sejumlah kelompok terror yang salah satunya adalah Abu Sayyaf Group. Abu Sayyaf Group kerap terlibat dalam berbagai aksi terror,

gov/primo?url=http://go.galegroup. $\mathrm{com} / \mathrm{ps} / \mathrm{i} . \mathrm{do} ? \mathrm{p}=\mathrm{AONE} \& \mathrm{sw}=\mathrm{w} \& \mathrm{u}=\mathrm{wa}$ sh89460\&v $=2.1 \& i d=$ GALE $\% 7 C A 126$ 198613\&it $=r \& a s i d=6 e c f 2$ befea $6 \mathrm{~b} 84 \mathrm{c} 0$ 3d00fbac70d19642, Internet (diakses tanggal 13 September 2016)

3 The National Security Strategy USA:http://www.state.gov/documents/ organization/63562.pdf, hal.1, 2002, Internet (diakses tanggal 13 September 2016) 
seperti pemboman, pembunuhan, penculikan maupun penyanderaan dan pemerasan. ${ }^{4}$ Hal itu tentu sangat meresahkan bagi masyarakat dan pemerintah Filipina yang tidak jarang juga menimbulkan banyak korban. Seperti kasus penyanderaan terhadap warga negara Amerika Serikat, Jeffrey Schilling yang diculik Abu Sayyaf Group pada 28 Agustus 2000 di Filipina. ${ }^{5}$ Dan penculikan dilakukan lagi pada bulan Mei 2001, terhadap 20 orang, dan telah membunuh satu dari 3 sandera asal Amerika Serikat dengan cara memenggal kepalanya. ${ }^{6}$ Pada akhir tahun 2001, Abu Sayyaf Group masih membawa 2 sandera warga negara Amerika Serikat yaitu pasangan Martin dan Gracia

4 Abu Sayyaf Group "Philippines, Islamist separatists":http://www.cfr. org/philippines/abu-sayyafgroupphilippines-islamist- separatists/p9235 Internet (diakses tanggal 27 Agustus 2016)

5 Inilah 15 Bukti Kekejaman Kelompok Abu Sayyaf "Tidak Segan Penggal Kepala Sandera”, didapat dari: http:// kaltim.tribunnews.com/2016/04/08/ inilah-bukti-sadisme-kelompok-abusayyaf-tidak-segan-penggal-kepalasandera? page $=4$, Internet (diakses tanggal 28 Agustus 2016)

6 Jejak Berdarah Penyanderaan Kelompok Abu Sayyaf, didapat dari:http:// news.detik.com/berita/3176560/ jejak-berdarah-penyanderaankelompok-abu-sayyaf,Internet (diakses tanggal28Agustus 2016)
Burnham serta seorang perawat warga negara Filipina bernama Ediborah Yap. ${ }^{\text {? }}$

Setelah Tragedi 9/11, Abu Sayyaf Group dianggap sebagai organisasi teroris oleh Amerika Serikat karena berbagai aksi-aksi tindakan terror dan diduga berafiliasi dengan jaringan teroris Al-Qaeda yang menjadi pelaku utama Tragedi 9/11. Dimana ada dugaan bahwa kemungkinan dari kedua kelompok ini menjalin hubungan untuk melakukan aksi kejahatan transnasional serta kaitan kelompok-kelompok terorisme lain untuk bertemu dalam mencapai kepentingan dan tujuan mereka. Melihat adanya indikasi keterkaitan dari kelompok-kelompok terorganisir tersebut, menjadikan tragedi ini tidak hanya sebatas berkaitan dengan isu ketertiban, namun juga perlu penerapan keamanan. ${ }^{8}$

7 Garnijanto Bambang Wahjudi, "Kerjasama Regional ASEAN Menghadapi Isu Terorisme Internasional", Penaganan Aksi Teroisme Internasional di Filipina Bagian Selatan Oleh ASEAN, hal. 84 Tahun 2000 dan 2001

8 Vermonte, Phillips, Regional Networking and coordination Againts International Terrorism: An Indonesia Perspective. The 13th Meeting of CSCAP Working Group Meeting on Transnational Crime, Manila 27-28 Juni2003. 
Isu terorisme, umumnya tidak hanya sebatas muncul dari wilayah regional tertentu saja seperti di Timur Tengah, namun telah menyebar ke wilayah-wilayah regional lainnya yang memiliki potensi konflik dan instabilitas. Filipina juga merupakan negara yang bisa saja memancing jaringan kelompok terorisme internasional lain untuk berafiliasi dengan kelompok di negaranya dan melakukan aksi-aksi terror yang lebih meluas, seperti aksi yang diterapkan oleh $\mathrm{Abu}$ Sayyaf Group dengan menculik dan meminta tebusan dengan maksud dan tujuan yang jelas di Filipina Selatan. Pada perkembangannya Abu Sayyaf Group ini dapat dinilai membahayakan keselamatan bagi warga dan kepentingan pihak lain. Dengan adanya kepentingan Amerika Serikat dalam melawan terorisme dan juga adanya kelompok terror di Filipina membuat kedua Negara ini sepakat untuk menjalin hubungan kerjasama dalam melawan aksi terror, dimana kerjasama ini tidak lagi hanya berfokus pada kerjasama yang berkaitan dengan ekonomi namun juga harus didukung oleh kerjasama lainnya di bidang keamanan dan sosial budaya. Dari pemaparan diatas, penulis berupaya untuk menjelaskan proses dipilomasi antara Amerika Serikat dan Filipina dalam memberantas Abu Sayyaf Group di Filipina.

\section{RumusanMasalah}

\section{Bagaimana Inisiatif Diplomasi Amerika Serikat Dalam Mem- berantas Abu Sayyaf Group di Filipina Selatan?}

\section{Temuan Dan Argumen}

Permasalahan mengenai kebijakan luar negeri Amerika Serikat sejak Tragedi 9/11 telah memberikan dampak perubahan yang amat signifikan terhadap penetapan hukum di dunia, dimana serangan terror tertentu telah berhasil membawa persepsi bahwa ancaman dapat terjadi kapan saja dan dapat memicu suasana kerusuhan serta sulit untuk di prediksi dengan tepat.

Adapun dari aktivitas terorisme internasional menyebar ke berbagai kawasan dunia yang telah banyak diteliti. Khususnya, yang berkaitan dengan jaringan teroris di Filipina menyangkut perkembangan dan keamanan (security). Corak dominan yang penulis temukan dalam tulisan-tulisan tersebut berpendapat bahwa, Tragedi 11 September tahun 2001 telah memberikan dampak perubahan terhadap kebijakan luar negeri Amerika Serikat dari aktivitas-aktivitas terorisme sebelumnya, dan yang lebih 
berkelanjutan lagi akan dijabarkan dalam tulisan-tulisan dibawah ini, dan dinilai sebagai continuity, atau kelangsungan dalam penelitian.

Setelah beberapa saat serangan terhadap Tragedi 9/11, pemerintah Amerika Serikat langsung mengeluarkan laporan rutin dari Depar temen Pertahanan Amerika Serikat, yaitu: "Quadrennial Defense Review Report (QDR)” pada tanggal 30 September 2001. ${ }^{9}$ Dan setelah setahun kemudian disusul dengan dikeluarkannya "The National Security Strategy (NSS 2002)"10 merupakan kebijakan dari strategi presiden George Walker Bush dalam menghadapi perubahan ancaman keamanan Amerika Sserikat pada $9 / 11$.

Transformasi cara pandang terhadap konsep strategi keamanan maupun pertahanan nampak terlihat jelas pada laporan QDR 2001 maupun di dalam NSS 2002. Bila dibandingkan sebelum masa Presiden Bush menjabat sebagai pemimpin, yaitu pada masa

9 Quadrennial Defense Report USA 2001,didapatdari:www.gao.gov/new. items/d0313.pdf, Internet (diakses tanggal 17 September 2016)

10 The National Security Strategy USA 2002, didapatdari:www.state.gov/ documents/organization/63562.pdf, Internet (diakses tanggal13 September 2016) presiden Bill Clinton kebijakan luar negeri Amerika Serikat selalu memperhatikan isu-isu berkaitan dengan ekonomi, penegakan Hak Asasi Manusia (HAM), serta nilainilai demokrasi. Hal ini terlihat dalam laporan "National Security Strategy (1999)"."11

Dapat dikatakan bahwa isuisu keamanan presiden Bush lebih cenderung pada pendekatan menggunakan hard power dalam strateginya, maka perkembangan baru dalam strategi keamanan dan pertahan nasional Amerika Serikat akan diikuti juga dengan transformasi di bidang militer, serta perubahan dalam strategi kebijakan luar negerinya.

Dalam buku Dr. Abuza berjudul "The Return Of The Abu Sayyaf" yang membahas keterkaitan hubungan Abu Sayyaf Group dan Al-Qaeda, dimana dalam bukunya tersebut dijelaskan bahwa Jamal Khalifa, saudara ipar Osama bin Laden, siap dikirim ke Filipina pada tahun 1991 dan mendirikan jaringan badan amal Islam. ${ }^{12}$ Khalifa

11 A national security strategy 1999, didapatdari:https://clinton4.nara. gov/media/pdf/nssr-1299.pdf, Internet (diakses tanggal18September 2016)

12 Khalifa's financial network, see Zachary Abuza, Funding Terrorism in Southeast Asia: The Financial Network of al Qaeda and Jemaah Islamiyah, NBR Analysis, 
secara resmi menjadi direktur regional untuk amal yang berbasis di Saudi, Islamic International Relief Organization (IIRO), dan bertanggung jawab tidak sebatas proyek di Filipina tapi juga di Indonesia, Thailand, dan Taiwan. ${ }^{13}$

Vol. 14, No. 5, Seattle: The National Bureau of Asian Research, December 2003, pp. 26-28.

13 The IIRO actually was established in 1978, but co-opted in 1979 by Saudi Arabian intelligence in order to serve as a financial conduit for Saudi, U.S., and Gulf-state funding to the Mujiheddin in Afghanistan. Through the 1980s, the IIRO legitimized itself and grew. It now has more than 30 offices, and its activities cover more than 75 countries. In the early 1990s, the IIRO decided to have separate directors for each of the countries, and Khalifa became the IIRO director for the Philippines. The IIRO claims to have begun charitable work in the Philippines in 1988, but according to documents registered at the Philippine Securities Exchange Commission (PSEC), the IIRO was legally incorporated in the Philippines on September 20, 1991, with offices in Makati and in several cities in Mindanao, including Cotabato and Zamboanga.Khalifa was listed as the IIRO's president and chairman of the board of trustees. Based on IIRO documents at the PSEC, Khalifa was one of five incorporators who signed the documents of registration; another was Khalifa'swife, Alice “Jameelah” Yabo. Dr. Adnan Khalil Basha, "Largest Islamic Relief Organization Maligned," Letter to the Editor, Philippine Daily Inquirer, August 2000, p.18; Christine Herrera, "Gemma Linked to Bin Laden Group
Keterkaiatan ini mengharuskan Amerika Serikat untuk bertindak menanggulangi Abu Sayyaf Group dalam perkembangan dengan jaringan transnasionalnya.

Adapun Jurnal Transnasional "Isu Terorisme dan beban ancaman keamanan kawasan Asia Tenggara pasca-runtuhnya WTC- AS" Tjarsono Idjang, menjelaskan Counter terrorism merupakan kesepakatan bersama dan upaya kerjasama yang dilakukan oleh pemerintah untuk melawan taktik, yang tidak begitu lama, tetapi memiliki penentuan jangka panjang dalam memerangi terror yang ditujukan kepada segala bentuk terror internasional yang telah menjadi perhatian seluruh dunia. ${ }^{14}$ Dalam hal ini, Amerika Serikat nampak menunjukan komitmennya tidak hanya sebatas berusaha untuk menangkap pemimpin Al-Qaeda maupun terhadap kelompok militannya yang dinyatakan oleh Amerika Serikat sebagai kelompok pelaku serangan pada 9/11, namun lebih menglobal Amerika Serikat mempelopori agar masyarakat

Funding Sayyaf, MILF,' Philippine Daily Inquirer, August 10, 2000.

14 Idjang Tjarsono, "Isu Terorisme dan beban ancaman keamanan kawasan Asia Tenggara pasca runtuhnya WTCAS”. Dalam Jurnal Transnasional, Pekanbaru Vol. 04 No.01, Juli 2012 
internasional berpartisipasi dalam perang melawan terorisme termaksud Abu Sayyaf Group di Filipina yang memiliki keterkaitan erat dengan jaringan Al-Qaeda.

Abu Sayyaf Group merupakan sebuah kelompok militan yang beroperasi di Filipina dan mempromosikan pendirian sebagai suatu negara Islam di Filipina Selatan yang berlokasi di Kepulauan Sulu dan Mindanao. Abu Sayyaf Group berdiri pada awal tahun 1990an oleh Abdurajak Janjalani atau yang biasa disebut dengan $\mathrm{Abu}$ Sayyaf. ${ }^{15}$ Abu Sayyaf Group terlibat dalam berbagai tindak kekerasan, seperti pemboman, pembunuhan, penculikan, penyanderaan maupun pemerasan. ${ }^{16}$ Seperti kasus penyanderaan terhadap warga negara Amerika Serikat, Jeffrey Schilling yang diculik Abu Sayyaf Group pada 28 Agustus 2000 di Filipina. ${ }^{17}$

15 Sholahuddin, "NII sampai JI, Salafy Jihadisme di Indonesia".Komunitas Bambu, hal. 25, Jakarta 2011

16 Abu Sayyaf Group "Philippines, Islamist separatists", didapatdari:http://www. cfr.org/philippines/abu-sayyafgroupphilippines-islamist-separatists/p9235 Internet (diakses tanggal27Agustus 2016)

17 Inilah 15 Bukti Kekejaman Kelompok Abu Sayyaf "Tidak Segan Penggal Kepala Sandera", didapat dari: http:// kaltim.tribunnews.com/2016/04/08/ inilah-bukti-sadisme-kelompok-abu-
Selain pembahasan diatas, ada kemiripan dari pengamatan sebelumnya seperti dalam buku Dr. Abuza. Ia menyampaikan bahwa ada keterkaitan antara Abu Sayyaf Group dan jaringan Al-Qaeda. Ada dua hal yang memeperlihatkan indikasi tersebut. Hal pertama adalah permintaan Osama bin Laden yang mengutus seorang wakilnya untuk merekrut pejuangpejuang Muslim dari Filipina untuk dilatih dan berperang di Afganistan. Hal kedua adalah kedatangan Mohammad Jamal Khalifa yang merupakan wakil dari Osama bin Laden ke Filipina untuk misi dalam mendirikan basis IIRO di Filipina. ${ }^{18}$. Hal ini yang menunjukan adanya dukungan Osama bin Laden kepada Abu Sayyaf Group dan mempererat ikatan antara Abu Sayyaf Group dengan Al-Qaeda.

sayyaf-tidak-segan-penggal-kepalasandera? page $=4$, Internet (diakses tanggal 28 Agustus 2016)

18 IIRO merupakan sebuah lembaga filantropis yang bergerak di bidang kemanusiaan yang dimiliki oleh Osama bin Laden. Didirikan di Filipina oleh tangan kanan yang juga merupakan saudara ipar Laden, Mohammad Jamal Khalifa. Lembaga ini diindikasi sebagai lembaga pendanaan yang mendanai operasi terorisme oleh Abu Sayyaf Group yang dikamuflasekan sebagai lembaga pengumpul dana bantuan untuk membangun masyarakat Muslim). 
Sedangkan menurut Simon Reeve yang merupakan penulis dari "The New Jackals: Ramzi Yousef, Osama bin Laden and the Future of Terrorism" menyatakan, bahwa pada musim panas di tahun 1991 terjadi pertemuan antara Khalifa, Abu Sayyaf yang merupakan pendiri dari Abu Sayyaf Group dan Ramzi Ahmed Yousef yang tidak lain adalah pelaku peledakan bom World Trade Center 1993 di Peshawar, Pakistan. (Berry, Curtis, Hudson, \& Kollars, 2002, hal. 10). Pertemuan ini disinyalir sebagai forum diskusi di antara ketiga tokoh tersebut untuk membicarakan rencana Khalifa dalam mendelegasikan Yousef ke Filipina dan memberikan pelatihan militer serta perakitan alat peledak yang berdaya ledak tinggi kepada pejuang Abu Sayyaf Group. Sedangkan dalam pembahasan buku Moeflich Hasbullah, "Asia Tenggara konsentrasi Baru Kebangkitan Islam", hal. 242". Menjelaskan bahwa Al-Qaeda tidak sebatas hanya membantu dengan dukungan berupa finansial saja, namun juga telah memberikan berbagai pelatihan kemampuan militernya terhadap anggota-anggota $\mathrm{Abu}$ Sayyaf Group. Hal ini diperjelas oleh pernyataan dari pejabat Militer Filipina, mengatakan bahwa Abu Sayyaf menerima bantuan materil dan finansial dan juga latihan militer dari jaringan Al-Qaeda pimpinan Osama bin Laden sampai tahun 1995, dua kelompok tersebut terus menjalin hubungan kerjasama dalam menjalankan aksi-aksi kejahatan transnasional mereka. ${ }^{19}$

Berdasarkan dari peristiwa tersebut hipotesa mengenai kebijakan Amerika Serikat dalam memberantas Abu Sayyaf Group di Filipina dapat terbentuk. Hal ini didasari atas opini bahwa aksi-aksi yang terorganisir dan pelatihan yang diberikan oleh Yousef kepada anggota Abu Sayyaf Group dan ikut sertanya Abu Sayyaf di dalam perang Afganistan, menerapkan nilai-nilai radikal dan fatwa mengenai diperbolehkan menculik bahkan membunuh untuk dijadikan sumber dana anggaran pada aksi mereka.

\section{MetodePenelitian}

Penelitian ini menggunakan metode deskriptif atau studi kepustakaan (library research). Pengumpulan data lebihdifokuskan pada informasi-informasi atau kajian yang diperoleh dari buku, surat kabar elektronik, dan publikasi dari instansi-instansi terkait

19 Moeflich Hasbullah, "Asia Tenggara konsentrasi Baru Kebangkitan Islam", Fokusmedia, hal. 242, Bandung 2003 
yang relevan dengan penelitian ini. Selain itu, data-data yang diperoleh berasal dari media internet sebagai penunjang informasi untuk keperluan analisis. Adapun kerangka pemikiran yang digunakan untuk menganalisa permasalahan dalam penelitian kerjasama antara pemerintah Amerika Serikat dan pemerintah Filipina menerapkan diplomasi yang lebih ditekankan secara bilateral dimana diplomasi tersebut dilakukan dalam kerangka soft power dan economic power. Economic power merupakan adanya hubungan diplomasi yang dilakukan antarnegara dengan menggunakan bantuan ekonomi baik berupa sumbangan dana, sogokan atau suap yang diberikan sebagai bagian dari bujukan dan paksaan untuk mematuhi atau melaksanakan ketetapan maupun strategi yang akan dipatuhi dan dilakukan secara bersama. Dalam hal ini Amerika Serikat turut memberikan dukungan dana finansial kepada pemerintah Filipina yang digunakan bersamasama dalam memerangi terorisme. ${ }^{20}$ Selain dalam bentuk economic power, diplomasi yang dilakukan

20 Economic Diplomacy and Economic Security,didapatdari: https://papers. ssrn.com/sol3/papers.cfm?abstract_ $\mathrm{id}=1436584$, Internet (diakses tanggal 20 September 2016) antara Filipina dengan Amerika Serikat menggunakan soft power yang dimana berbeda dengan yang dilakukan terhadap Irak dan juga Afganistan yang menggunakan pendekatan hard power. Seperti dengan economic power, soft power digunakan dalam berdiplomasi sebagai suatu bujukan dan desakan yang dilakukan secara halus melalui penerapan dan pertukaran nilai-nilai dan budaya bersama yang dituangkan ke dalam suatu kerangka kerjasama tanpa melibatkan serangan militer. Hal ini juga berlaku dan sama dengan diplomasi oleh Indonesia, Amerika Serikat, Filipina dalam memerangi terorisme dimana dalam melakukan diplomasi, Amerika Serikat memberikan dukungan penuh untuk menemukan ide bersama, melakukan kerjasama dalam melawan terorisme yang merupakan ancaman bagi keamanan global.

\section{KerangkaTeori}

Terkait dengan masalah terorisme, memang hingga pada akhir ini tidak ada informasi mengenai definisi yang disepakati secara kolektif untuk pengunaan terorisme. Namun dari berbagai kalangan pakar sosial dan politik barat memiliki kesepakatan dalam mendefinisi atau menjelaskan 
arti terorisme. Terror atau Terorisme tidak selalu identik dengan kekerasan. Arti terror atau dalam bahasa Perancis, terreur merupakan arti yang biasa digunakan para pejuang revolusi perancis terhadap tindakan pembunuhan, kebuasan maupun anarkis, yang dilakukan tanpa melakukan proses peradilan pada saat revolusi perancis berlangsung antara tahun 1793 hingga $1794 .{ }^{21}$ Selain itu, terorisme didefinisikan sebagai usaha-usaha atau aktivitas untuk menciptakan rasa takut yang mendalam melalui upaya-upaya pembunuhan, pemboman, perusakan, penghacuran secara tiba-tiba, penculikan atau penyanderaan dan tindakan kekerasan yang lainnya, yang biasanya menimbulkan korban terhadap masyarakat sipil yang tidak bersalah.

Persoalan pendefinisian term terorisme merupakan hal yang rumit, karena ia identik dengan masalah moral, serta cara penilaianpun tidak tunggal. Definisi tentang terorisme juga telah di upayakan oleh berbagai kalangan, terutama pihak Amerika Serikat yang sangat

21 Sejarah Revolusi Perancis, didapat dari: http://www.zonasiswa.com/2015/07/ revolusi-perancis-latar-belakangproses.html Internet (diakses tanggal 13 Oktober 2016). berkeinginan atau kepentingan terhadap War on Terrorism.22

Berdasarkan literatur ilmu politik, politik teror memiliki empat komponen yaitu: Pertama, kekerasan adalah merupakan bagian yang dibutuhkan dalam membuat aksi politik. Apalagi kekerasan yang berbentuk secara dramatis, menjadi strategi yang dianggap paling efektif untuk merebut perhatian dunia. Semakin dunia memberi perhatian, semakin sukses aksi politik terror. Pesan politik yang ingin ditunjukan mereka dapat disampaikan spektrumnya meluas dan sukses ketika perhatian publik dapat diraih.

Kedua, menggunakan tujuan dengan menghalalkan segala cara. Seringkali dibalik terror berbagai aksi ada tujuan mulia. Tujuan itu digunakan dapat berupa misi ideologis, bahkan keagamaan. Kemungkinan juga tujuannnya adalah bagian dari kepentingan politik suatu kelompok yang tertindas untuk meraih hak dasar mereka. Namun politik terror menghalalkan segala cara sejauh itu dapat efektif untuk mencapai

22 Drs. Sudarto, Manajemen Krisis Dalam Menanggulangi Terorisme,didapat d a r i h t t p s: / / w w w. kem han . go.id/2012/05/23/manajemen-krisisdalam-penanggulangan-terorisme. html, Internet (diakses tanggal 21 September 2016) 
tujuan mereka. Bahkan jika untuk mencapai tujuan itu, tak bisa dimungkiri menjadikan manusia sebagai tumbal, termasuk korban dari rakyat tidak berdosa, itupun dapat ditempuh.

Komponen yang Ketiga adalah gerakan terselubung. Aksi terror dilakukan dalam sebuah kelompok jaringan kerja yang secara sengaja disembunyikan di bawah permukaan. Mereka tidak mempercayai bahwa mekanisme politik konvensional dapat memenuhi tercapainya aspirasi politik yang mereka perjuangkan. Politik non konvensional dipilih karena dianggap satu-satunya mekanisme yang tersedia untuk turut bicara dan didengar.

Keempat, militansi dan fanatisme dari dalam diri pelaku. Berbeda dengan politik konvensional, politik terror didukung personel yang loyal dan militan. Apalagi jika misi utama dari kelompok itu bernuansa keagamaan atau kemerdekaan sebuah bangsa. Aksi nekat yang berakhir dengan kematian dari pelaku seperti bunuh diri adalah hal yang biasa. ${ }^{23}$.

23 Meriam Budiardjo, "Teror dalam Tatanan Struktur Politik” PT. Gramedia, hal 52, Jakarta 2001
Asia Tenggara merupakan sebuah kawasan yang difokuskan oleh Amerika Serikat untuk menerapkan kampanye maupun strategi dalam perang menghadapi ancaman terorisme. Alasan mengapa Asia Tenggara dijadikan "Second Front" oleh Amerika Serikat dikarenakan ditemukannya sejumlah dokumen terkait akan adanya penyerangan beroperasi yang akan dilakukan oleh kelompok terorisme mengenai fasilitas baik dalam fasilitas militer maupun diplomatik dan kepentingan lainnya milik Amerika Serikat di beberapa negara Asia Tenggara seperti di Filipina. Selain adanya dokumendokumen yang ditemukan tersebut, kawasan Asia Tenggara dijadikan "second front" oleh Amerika Serikat dan juga sekutu-sekutunya dalam memerangi bahaya terorisme dikarenakan adanya beberapa alasan, yang dimana beberapa alasan tersebut adalah: ${ }^{24}$

Pada umumnya, negara-negara Asia Tenggara merupakan negara yang berkembang, yang dimana kemiskinan masih menyelimuti negara-negara tersebut sehingga

24 Tan, Andrew, "Southeast Asia as the Second Front" in the War Against Terrorism: Evaluating the Threat and Responses"dalam Terrorism and Political Violance, vol.15 No.2, Frank Cass hlm.112, London 2003. 
rawan terjadinya konflik yang dikuti dengan lemahnya hukum institusi membuat kawasan ini dianggap sebagai potensi dan juga tempat titik temu dari para kelompok teroris untuk tumbuh dan berkembang dalam memperoleh anggota-anggota mereka dan juga menyusun strategi yang digunakan untuk meneror dan juga negara Asia Tenggara dengan kondosisi topologinya yang berpulau-pulau menyebabkan keadaan wilayahnya memiliki banyak hutan yang dimana hutan tersebut dimanfaatkan oleh para kelompok teroris untuk membentuk kamp pelatihan, berkumpul dengan anggota lainnya dan digunakan untuk bersembunyi.

Kelompok-kelompok terror yang sudah ada sebelum Tragedi 9/11 seperti Abu Sayyaf Group di Filipina Selatan, Jammah Islamiyah di Indonesia dan Malaysia yang dimana kelompok tersebut merupakan kelompok islamis yang bersifat radikalis, separatis, dan ekstremis, yang setelah kejadian Tragedi 9/11 dikategorikan sebagai daftar dari jaringan teroris yang berbahaya oleh Amerika Serikat yang dimana dua kelompok tersebut dikaitkan sebagai kelompok perpanjangan tangan yang berada di Asia Tenggara dengan organisasi jaringan teorirs internasional yaitu Al-Qaeda.
Selain itu adanya sejumlah peristiwa-peristiwa terror setelah kejadian Tragedi 9/11 yang di wilayah Asia Tenggara yang dimana peristiwa tersebut menjadi sorotan dimata dunia internasional yang selain merupakan tindakan kekerasan hal itu juga menimbulkan jatuhnya banyak korban baik korban didalam negerinya sendiri maupun korban wisatawan asing, di Indonesia adanya kejadian Bom Bali I, Bom Bali II, Bom JW Marriot, di Filipina Selatan adanya pengeboman pada kapal ferry di teluk Filipina dan juga adanya pengeboman pada Bandara Davao serta penculikan maupun penyanderaan yang berulang kali dari aksi kelompok terror.

Kebijakan kontraterorisme Amerika Serikat menyimpulkan dari setiap aksi tindakan teroris maupun kriminal tidak dapat diberi toleransi dan mengecam tindakan-tindakan tersebut tanpa membedakan apapun motivasi dan tujuan mereka serta tidak akan membuat perjanjian ataupun kesepakatan terhadap jaringan teroris sebab, hal itu hanya akan memancing lebih banyak tindakantindakan yang dilakukan kelompok terror. $^{25}$

25 Ibid., 
Hubungan Abu Sayyaf Group Dengan Kelompok-Kelompok Terorisme

Pada September tahun 2001, militer Filipina mengkonfirmasi secara spekulatif bahwa Al-Qaeda telah menunjukkan dukungannya dengan memberi bantuan, baik material, kepemimpinan, dan pelatihan. Sebagai sebuah organisasi teroris transnasional, Al-Qaeda telah berkembang melalui daerahdaerah Timur Tengah, Eropa Barat, Amerika Utara, dan Asia Selatan. Hingga kawasan Asia Tenggara sebagai basis kunci dan daerah persiapan. Pada awalnya, Abu Sayyaf didanai melalui jaringan finansial yang didirikan oleh Muhammad Jamal Khalifa, saudara Osama bin Laden, yang telah diutus ke Filipina pada 1991, dan mendirikan sebuah jaringan amal Islam. Khalifa adalah anggota resmi yang langsung bersentuhan ke daerah untuk basis amal Saudi, The Islamic International Relief Organization (IIRO), dukungan ini tidak hanya untuk Filipina tetapi juga kelompok radikal di Indonesia, Thailand dan Taiwan. ${ }^{26}$ Selain hubungan dengan Al-Qaeda yang telah memberi dukungan secara finansial dari gerakan ini, Abu Sayyaf juga menjalin hubungan

$26 \quad$ Ibid., hal 5 dengan JI (Jamaah-Islamiyyah) di Malaysia.

Al-Qaeda tidak sebatas mendukung secara finansial saja, namun juga telah memberikan berbagai pelatihan kemampuan militernya terhadap anggota-anggota $\mathrm{Abu}$ Sayyaf Group. Hal ini diperjelas oleh pernyataan dari pejabat Militer Filipina, mengatakan bahwa $\mathrm{Abu}$ Sayyaf menerima bantuan materil dan finansial dan juga latihan militer dari jaringan Al-Qaeda pimpinan Osama bin Laden sampai tahun 1995, dan dua kelompok tersebut terus menjalin hubungan kerjasama dalam menjalankan aksiaksi kejahatan transnasional. ${ }^{27}$

\section{Perbedaan Abu Sayyaf Group Dengan Kelompok-Kelompok Separatis di Filipina}

Akar permasalahan ini bisa dilacak dari terbentuknya Moro National Liberation Front (MNLF), MNLF adalah salah satu organisasi pertama dari golongan separatis Moro selama sekitar dua dekade dari 1970-an. ${ }^{28}$ Kelompok tersebut berjuang demi kebebasan Muslim

\footnotetext{
27 Moeflich Hasbullah, "Asia Tenggara konsentrasi Baru Kebangkitan Islam,"ed, Op. Cit., hal. 242

28 Front Pembebasan Nasional Moro, https:// id.wikipedia.org/wiki/Front_Pembebasan_ Nasional_Moro, Internet (diakses tanggal 29 Januari 2017)
} 
Moro yang meliputi wilayah kelompok sendiri. Dan yang ketiga Mindanao, Palawan dan Sulu. adalah Abu Sayyaf Group yang Empat kelompok lainnya adalah terbentuk pada tahun 1990-an. ${ }^{30}$ seperti Moro Islamic Liberation Front Moro (MILF), MILF muncul sebagai hasil dari kesepakatan damai antara MNLF dan pemerintah pusat Filipina. ${ }^{29}$ Ketika itu penduduk boleh menyatakan pilihannya untuk bergabung dalam wilayah otonomi Muslim dan hasilnya empat wilayah meliputi Tausug, Maranao, Maguindanao, dan Banguingui memilih untuk bergabung. Meskipun begitu kesepakatan itu tidak cukup memuaskan sebagian pejuang Walaupun ada yang belakangan adalah Bangsamoro Islamic Freedom Fighter (BIFF) yang dipimpin Abu Misri dan Red Gun Soldier (RGS) yang hanya sebatas kelompok petani bersenjata biasa. Dari lima kelompok tersebut, empat diantaranya MNLF, MILF, Abu Sayyaf Group dan BIFF memiliki tujuan yang sama yakni ingin mendirikan sebuah Negara islam di Mindanao Filipina Selatan dan pembangunan ekonomi di wilayah mereka. ${ }^{31}$ Muslim sehingga MILF membentuk

\section{Gambar 1: Area Terror Abu Sayyaf Group}

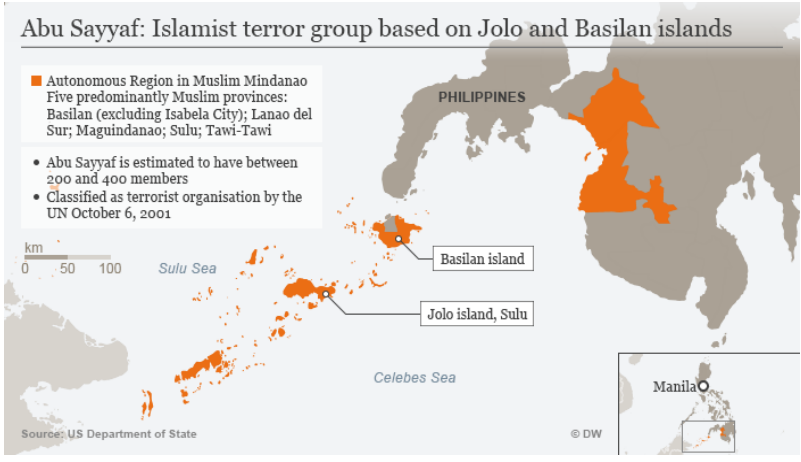

Sumber: www.dw.com/image/19178900_303.png Gambar: Internet (diakses tanggal 14 Februari 2017)

29 Suku Moro, https://id.wikipedia.org/ wiki/Suku_Moro, (diakses tanggal 29Januari 2017)
30 Garnijanto Bambang Wahjudi, "Kerjasama Regional ASEAN Menghadapi Isu Terorisme Internasional (Penaganan Aksi Teroisme Internasional di Filipinai Bagian Selatan Oleh ASEAN Tahun 2000 dan 2001)",Tesis: Fakultas Ilmu Sosila Dan Politik Program Pasca sarjanaUniversitas Indonesia, hal 64, 2003

31 Ibid., 
Hal yang membedakan Abu Sayyaf Group dengan kelompok separatis lain di Filipina adalah aksi-aksinya seperti peledakan di bandara Davao, pengeboman kapal feri di teluk Filipina, selain aksi-aksi tersebut juga kerap menculik warga asing seperti warga negara Amerika Serikat menimpa Jeffrey Schilling yang diculik Abu Sayyaf Group pada 28 Agustus 2000, dan penculikan dilakukan lagi pada bulan Mei 2001, terhadap 20 orang, dan telah membunuh satu dari 3 sandera asal Amerika Serikat dengan cara memenggal kepalanya. ${ }^{32}$ Pada akhir tahun 2001, Abu Sayyaf Group masih membawa 2 sandera warga negara Amerika Serikat yaitu pasangan Martin dan Gracia Burnham serta seorang perawat warga negara Filipina bernama Ediborah Yap. ${ }^{33}$

Dengan adanya tindakantindakan maupun aksi yang dilakukan oleh Abu Sayyaf Group tersebut pemerintah Filipina dan

32 Jejak Berdarah Penyanderaan Kelompok Abu Sayyaf, didapat dari: http://news. detik.com/berita/3176560/jejakberdarah-penyanderaan-kelompokabu-sayyaf, Internet (diakses tanggal 28 Agustus 2016)

33 Garnijanto Bambang Wahjudi, "Kerjasama Regional ASEAN Menghadapi Isu Terorisme Internasional (Penaganan Aksi Teroisme Internasional di Filipinai Bagian Selatan Oleh ASEAN Tahun 2000 dan 2001)", hal. 84 juga pemerintah Amerika Serikat mengecam bahwa hal tersebut merupakan tindakan terorisme yang harus dilawan dan diperangi. Abu Sayyaf Group didefinisikan sebagai daftar jaringan kelompok terorisme selain aksi-aksinya, dan diduga memiliki keterkaitan dengan kelompok jaringan Al-Qaeda yang dituduh oleh Amerika Serikat sebagai pelaku utama peristiwa 9/11 yang dipimpin oleh Osama Bin Laden. ${ }^{34}$ Sehingga dalam hal ini, Amerika serikat mendesak dan menawarkan bantuan kerjasama yang dilakukan dengan berdiplomasi terhadap Filipina dan juga negara Asia Tenggara lainnya untuk melawan tindakantindakan terror yang dilakukan oleh kelompok tersebutdan juga dapat mengancam keamanan global.

\section{Inisiatif Diplomasi Amerika Serikat Dan Filipina Dalam Menga- tasi Isu Terorisme}

Sebelum tragedi $9 / 11$, hubungan antara Amerika Serikat dan Filipina terjalin sudah berlangsung sejak lama, dimulai pada saat kolonialisasi Amerika Serikat terhadap Filipina

\footnotetext{
34 Filipina Tangkap Pentolan Kelompok Abu Sayyaf, https://m.tempo.co/read/ news/2012/07/30/118420166/filipinatangkap-pentolan-kelompok-abusayyaf, Internet (diakses tanggal 08 Februari 2017)
} 
tahun $1905 .{ }^{35}$ Selepas Filipina merdeka hubungan tersebut masih berjalan dengan baik dimana pasukan militer Amerika Serikat kerap menempatkan basis pelatihan militernya di wilayah Filipina. ${ }^{36}$ Setelah Tragedi 9/11, pemerintah Amerika Serikat menerapkan inisiatifnya untuk menghadapi ancaman terorisme. Inisiatif tersebut langsung mendapat persejutuan dan dukungan sangat baik oleh pemerintahan Filipina. Kerja sama di bidang militer tersebut masih berlangsung hingga sekarang dan membuat hubungan kedua negara semakin erat, khususnya dalam bidang pertahanan dan keamanan negara.

Dukungan dan simpatisan yang diperlihatkan oleh pemerintah Filipina yang pada saat itu dipimpin oleh Presiden Gloria Macapagal Arroyo paska kejadian 9/11, yang menghancurkan Gedung World Trade Center di New York dan Pentagon adalah dengan melakukan panggilan telepon terhadap Presiden George Walker Bush sebagai

35 Sejarah Filipina, didapat dari: https:// id.wikipedia.org/wiki/Sejarah_ Filipina, Internet (diakses tanggal 26 Januari2017)

36 Mahajan, Melawan Negara Teroris: Dominasi Amerika Serikat terhadap Irak \& kedaulatan dunia, MizanPustaka, hal.45, Jakarta2005
Presiden Amerika Serikat yang pada saat itu juga turut menyatakan simpati terhadap tragedi tersebut dan juga mendukung ide dari strategi Presiden George Walker Bush dalam perang melawan terorisme. Tindakan yang dilakukan oleh Presiden Gloria Macapagal Arroyo tersebut adalah sebagai perwakilan pertama dari pemerintah kawasan Asia Tenggara mengenai dukungannya terhadap pemerintah Amerika Serikat dalam perang melawan terorisme.

Hubungan bilateral kedua negara dilanjutkan dengan menghasilkan suatu kesepakatan kerjasama mengenai masalah terorisme, dengan adanya perjalanan Presiden Gloria Macapagal ke Amerika Serikat yang dilakukan pada bulan November 2001 dalam rangka merayakan hubungan perjanjian kerjasama antara Amerika Serikat dan Filipina dalam bidang pertahanan yang sudah berlangsung selama 50 tahun yaitu Mutual Defense Treaty (MDT). ${ }^{37}$ Selain melakukan perayaan itu, kedua pemimpin tersebut sepakat mengeluarkan sebuah kesepakatan perjanjian bersama yang diyakini bergabung dalam kerjasama militer, dimana kerjasama militer tersebut dilakukan sebagai

37 Ibid., 
sebuah tindakan bantuan oleh Amerika Serikat terhadap Filipina dengan memperkuat pasukan militer keamanan Filipina dalam memerangi terorisme dan juga dilakukannya untuk menghentikan sejumlah aksi terror yang dilakukan oleh Abu Sayyaf Grouplantaran meresahkan pemerintah dan mengusik keamanan masyarakat Filipina.

Sebelumnya, pertemuan kedua pemerintah tersebut telah menghasilkan suatu kerangka legal kerjasama untuk menghadirkan para personil militer Amerika Serikat ke wilayah Filipina dimana program tersebut dinamakan dengan persetujuan bersama yaitu Visiting Forces Agreement (VFA). Sebelumnya jugapernah dibentuk program kerja sama oleh kedua negara, namun berhenti pada tahun 1991. Tapi tak lama setelahnya lanjutkan kedua negara membentuk kerjasama baru dalam VFA sebagai bagian dari program Amerika Serikat dan Filipina yang biasa disebut dengan "Joint Exercise" untuk menghadirkan pasukan militer Amerika Serikat di wilayah Filipina. $^{38}$

Program Baliktan tersebut merupakan bagian VFA dimana program tersebut dilakukan untuk melatih pasukan tentara Filipina dan juga membantu perlengkapan serta persenjataan terhadap militer Filipina untuk melakukan operasi dalam menghadapi Abu Sayyaf Group di wilayah Filipinan selatan seperti di wilayah Basilan, Sulu, dll yang dianggap sebagai wilayah operasional Abu Sayyaf Group.

Penempatan pasukan militer Amerika Serikat ke wilayah Filipina selatan merupakan bentuk hubungan aliansi antara kedua Negara dengan mengerahkan pasukan bersenjata Filipina yang diberi keterampilan dan nasihat dalam sebuah operasi melawan kelompok terror. ${ }^{39}$ Kedatangan pasukan Amerika Serikat tersebut adalah selain memberikan latihan militer mereka juga memberikan berbagai bantuan mengenai taktik, psikologi, intelegensi yang merupakan bagian dari strategi baru dalam menghadapi sebuah peperangan dan juga untuk menggempur $A b u$ Sayyaf Group dalam melakukan perlawanan tersebut dilakukan secara sembunyi-sembunyi.

Selain dalam program militer, bantuan kerjasaman yang dihasilkan di dalam kunjungan bilateral itu merupakan bagian dalam pem-

39 Ibid.,

38 Ibid., 
bahasan strategi economic power yaitu dengan dengan mengeluarkan program dana bantuan Amerika Serikat yang digunakan untuk memberikan pendidikan latihan militer dalam menghadapi kelompok terror. ${ }^{40}$ Sumbangan dana tersebut juga dilakukan untuk mendukung dan melengkapi keperluan logistik seperti persenjataan, fasilitas transportasi untuk angakat darat, laut, udara, dll. Selain itu bantuan ekonomi tersebut digunakan untuk mengatasi kekacauan di dalam negeri yang membuat perkenomian Filipina mengalami kemerosotan akibat pebuatan kelompok terror dan kerusakan sejumlah tempat seperti bandara Davao yang dilakukan oleh Abu Sayyaf Group.

Adanya bantuan dana, pelatihan militer dan bantuan-bantuan lain yang diberikan Amerika Serikat terhadap Filipina dalam program perang melawan terorisme merupakan bantuan terbanyak jika dibandingkan dengan bantuanbantuan yang diberikan Amerika Serikat pada negara-negara lainnya yang ada di kawasan Asia Tenggara dan merupakan kedua di dunia.

40 Economic Diplomacy and Economic Security,https://papers.ssrn.com/sol3/ papers.cfm?abstract_id $=1436584$, Internet (diakses tanggal 26 Januari 2017)
Selain itu pemerintah Filipina juga memberikan fasilitas di lapangan udara maupun di pelabuhan yang digunakan oleh Amerika Serikat untuk melakukan transit dan juga digunakan sebagai pengawasan berjaga-jaga dalam menjaga keamanan wilayah Filipina maupun Negara-negara tetangga dari serangan ancaman terror.

Dalam penegasan ini, pemerintah Filipina menunjukan kedekatan hubungan diplomatiknya terhadap pemerintah Amerika Serikat, yang menunjukan konsolidasi, kohesivitas dan efektivitas kerjasama maupun eksistensinya sebagai pemimpin pertama dari Asia Tenggara yang mengunjungi gedung putih di Washington sejak pergantian presiden Amerika Serikat yaitu Barrack Obama. Dalam pertemuan diplomatik antara presiden Arroyo dengan Barrack Obama dimana kedua pemimpin negara tersebut mengeluarkan sebuah pernyataan bersama untuk meningkatkan dan memperkuat hubungan kerjasama dalam bidang anti terorisme, dengan bergantinya presiden Amerika Serikat yaitu Barrack Obama, bukan berati program melawan teroris terlepas begitu saja, dengan adanya pertemuan antara kedua presiden tersebut yang dimana pertemuan 
diplomatik dilakukan pada bulan Agustus tahun 2009, dimana dari kedua negara tersebut saling berkomitmen untuk bersamasama menjaga keamanan regional bersama. Dalam pertemuan ini juga presiden Barrack Obama berharap kepada pemerintah Filipina untuk bertindak sebagai perantara membangun hubungan kerjasama regional bersama dengan anggota ASEAN lainnya, karena bagi kedua pemerintah tersebut pentingnya untuk menjaga kestabilan dan keamanan regional Asia Tenggara khususnya dari ancaman terorisme. Dalam pertemuan yang berlangsung tidak lama ini juga membahas kesepakatan kerjasama dalam bidang lainnya seperti ekonomi, lingkungan, namun yang paling difokuskan adalah mengenai bidang keamanan dan juga masalah terorisme.

Memberi Bantuan Pasukan Terhadap Pemerintah Filipina

Permasalahannya sebagaimana kita ketahui bersama bahwa Amerika Serikat adalah negara super power yang memiliki kemampuan mumpuni diberbagai bidang. Bila ditelusuri dari segi kapabilitas power yang dimiliki Filipina di bidang ekonomi, militer, dan politik. Tentu amat tidak sebanding dimiliki oleh Amerika Serikat bila mengingat usia pendirian negaranya, bahkan lemah di tingkat internasional. Filipina merupakan sekutu utama Amerika Serikat di kawasan Asia Tenggara sekaligus mitra politik, ekonomi maupun militer untuk perang melawan terorisme. Dari kolaborasi yang didukung secara khusus oleh Amerika Serkat dalam bidang ekonomi dan militer, menunjukan bahwa kerjasama kontraterorisme antara Amerika Serikat dan Filipina menempuh upaya-upaya baru dalam langkah menjaga keamanan maupun stabilitas melalui peningkatan militer. Dengan adanya kepentingan bersama ini, Amerika Serikat dan Filipina yang fokus terhadap permasalahan khususnya security dan menempatkan permasalahan terorisme sebagai sebuah permasalahan bersama yang harus segera diatasi. ${ }^{41}$

Menurut William D. Coplin, kebijakan luar negeri setiap negara adalah sebuah refleksi aspirasi negara yang bersangkutan dalam berhadapan dengan negara lain di seluruh dunia. Politik luar negeri tersebut paling tidak dipengaruhi oleh tiga faktor: kondisi politik dalam negeri (domestic politics), kemampuan ekonomi dan militer,

41 Asvi Warman Adam, dkk, Konflik Teritorial di Negara-Negara ASEAN, Jakarta: PPW-LIPI, 1992 
serta lingkungan internasional. ${ }^{42}$ Ketiga faktor ini juga yang ikut mempengaruhi politik luar negeri Amerika Serikat dalam memerangi masalah terorisme.

Filipina menerima bantuan pelatihan dan mobilitas peralatan militer dari Amerika Serikat. Setelah Presiden Bush berjanji untuk menyediakan juta dolar untuk bantuan militer yang termasuk pesawat angkut C-130 dan 30,000 senapan M16 yang di rekondisikan sekitar US\$4,6 miliar dukungan dana ekonomi di tahun 2001, dan US $\$ 15$ miliar yang akan di gunakan sebagai anggaran dibutuhkan untuk tahun 2002, anggara ini tergolong besar dan terbanyak jika dibanding bantuan di negara-negara kawasan Asia dan merupakan kedua di dunia. Pembiayaan untuk belajan peningkatan perangkat militer seperti belanja senjata meningkat dari US $\$ 1,4$ juta, kemudian US $\$ 2$ juta, dan US $\$ 19$ juta dalam periode yang sama. ${ }^{43}$

42 Lihat William D. Coplin, Pengantar Politik Internasional (terj), Bandung, Sinar Baru, 199

43 Andrew Feickert, For more on U.S. military operations in the Philippines, "U.S. Military Operations in the Global War on Terrorism: Afghanistan, Africa, the Philippines, and Colombia", hal. 9-12, CRS report for Congress, 2005
Sebelumnya, dalam menanggulangi kelompok terror, Angkatan Bersenjata Filipina atau Armed Forces of the Philippines (AFP) telah melakukan penyeranganpenyerangan seperti Abu Sayyaf Group. Namun Abu Sayyaf Group dapat dikatakan sangat sulit di berantas, salah satunya karena Abu Sayyaf Group berlokasi di pedalaman Kepulauan Basilan. Hal ini juga yang menjadikan dasar bagi pemerintah Filipina meminta dukungan kepada pemerintah Amerika Serikat untuk membantu menanggulangi kelompok terror. Amerika Serikat mendukung kebijakan pemerintah Filipina untuk menanggulangi Abu Sayyaf Group di Filipina Selatan. ${ }^{44}$

Coplin juga menyebutkan, bahwa setidaknya ada tiga aspek kekuatan dan kelemahan militer di dunia dewasa ini (1) kapasitas relatif negara-negara untuk menggunakan kekuatan militer pada tiga tingkat yang berbeda; nuklir, konvensional dan subversif (2) tingkat kebergantungan negaranegara pada sumber-sumber luar negeri untuk perlengkapan militer (3) ketidakstabilan dalam negeri

44 The National Security Strategy USA, hal. 5, 2002:www.state.gov/documents/ organization/63562.pdf, Internet (diakses tanggal 13 September 2016) 
mempengaruhi kemampuan militer. Selain itu, ada 3 kriteria terpenting dalam kekuatan militer (1) jumlah pasukan (2) tingkat pelatihan (3) sifat perlengkapan militer. ${ }^{45}$

Amerika memberikan bantuan pasukan militer ke Filipina untuk melatih AFP guna menghadapi kelompok terror termaksud $\mathrm{Abu}$ ayyaf Group. ${ }^{46}$ Amerika Serikat mulai mengerahkan pasukannya ke Filipina dengan jumlah kurang lebih 660 personil yang terdiri atas 160 pasukan khusus, ditambah dengan 500 personil untuk pendukung. ${ }^{47}$ Hal tersebut untuk menindaklanjuti kesepakatan pemerintah Amerika Serikat dan pemerintah Filipina untuk mengadakan training exercise atau latihan militer gabungan pada

45 Dahlan Nasution, Politik Internasional Konsep dan Teori, hal 26, Erlangga Jakarta 1989.

46 Steven Mufson, "U.S. to Aid Philippines' Terrorism War", Washington Post, 21 November 2001. Dikutip http:// www.elib.unikom.ac.id/download. php?id=143138.pdf, (diakses tanggal03September 2016)

47 Shedon W. Simon, "Southeast Asia and The War on Terrorism", dalam Managing Security Challenges in Southeast Asia, NBR Analysis: Vol.13, 4 July 2002 (The National Bureau of Asian Research: Washington D.C., 2002), hal. 32 tahun 2002 selama kurang lebih 6 (enam) bulan di Pulau Basilan, tempat dimana Abu Sayyaf Group beroperasi. ${ }^{48}$

Gambar 2: Pesawat kargo C-130 AS

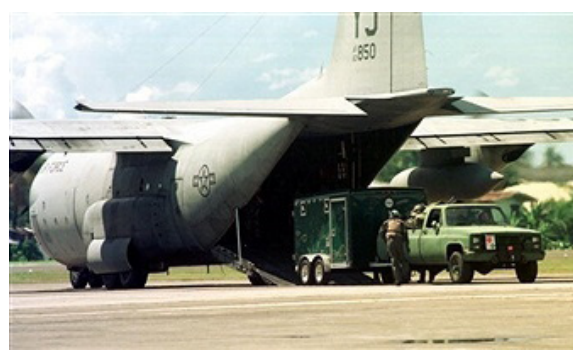

Sumber: www.gettyimages.com/ license/ 693255

Gambar: Internet (diakses tanggal 15 Februari 2017)

Sebuah truk dan trailer diturunkan dari sebuah pesawat kargo C-130 Amerika Serikat pada 20 Januari 2002 di Pangkalan Angkatan Udara Andrews di Zamboanga City di Filipina selatan. Pesawat kargo C-130 mengirimkan lebih banyak peralatan ke pangkalan udara untuk keperluan lebih dari 600 tentara Amerika Serikat yang akan membantu melatih AFP dalam kontraterorisme.

48 John Roberts, "US Training exercise in the Philippines sets stage for Broader military operations”, 15 Maret2002. 
Menerapkan Pendekatan Sosial Dan Budaya Dalam Penangan Terorisme

Politik luar negeri atau kebijakan luar negeri Amerika Serikat memutuskan untuk melakukan kerjasama dengan pemerintah Filipina, titik temu darikepentingan bersama antara kedua Negara dalam memberantas kelompokterro. Fokus utama adalah permasalahan security dan menempatkan permasalahan terorisme ini sebagai sebuah permasalahan bersama yang harus segera diatasi. ${ }^{49}$ Dalam penegasan ini, bahwa pemerintah Amerika Serikat dan pemerintah Filipina tidak hanya berfokus pada kerjasama yang berkaitan dengan ekonomi namun juga didukung oleh kerjasama lainnya yaitu di bidang keamanan dan sosial budaya.

Sebelum terjadinya Tragedi 11 Septembertahun 2001, sebenarnya Amerika Serikat telah mengarahkan peningkatkan kekuatan militernya di Filipina pada bulan September 2000, pada saat itu Laksamana C. Blair Dennis, Komando Operasi Khusus Pasifik (SOCPAC), menuju ke Manila untuk memberikan bantuan kepada pemimpin AFP dalam konsep yang bergerak pada Pelatihan Tim (MTT) yang di-

49 AsviWarman Adam, dkk, Op.Cit. rancang untuk melatih dan mempersenjatai AFP. ${ }^{50}$

Amerika Serikat dan Filipina pertama kali mengadakan latihan gabungan militer pada Maret tahun 2001 dengan pasukan Light Reaction Company (LRC) yang dibentuk oleh Amerika Serikat, khusus untuk menghadapi terorisme di Filipina. ${ }^{51}$ Hal tersebut terkait dengan kasus penyanderaan terhadap warga negara Amerika Serikat, Jeffrey Schilling yang diculik oleh $\mathrm{Abu}$ Sayyaf Group pada 28 Agustus $2000 .^{52}$ Serta penculikan pada bulan Mei 2001, terhadap 20 orang, dan telah membunuh satu dari 3 sandera asal Amerika Serikat dengan cara memenggal kepalanya di Filipina

50 Briscoe, C.H. "Balikatan exercise spearheaded ARSOF operations in the Philippines." Special Warfare, Sept. 2004,elibraryusa.state.gov/ primo?url=http://go.galegroup.com/ ps/i.do? $\mathrm{p}=\mathrm{AONE} \& \mathrm{sw}=\mathrm{w} \& \mathrm{u}=$ wash 894 $60 \& v=2.1 \& i d=$ GALE\%7CA126198613 \&it $=$ r\&asid $=6$ ecf2 2 efea $6 \mathrm{~b} 84 \mathrm{c} 03 \mathrm{~d} 00 \mathrm{fba}$ c70d19642, Internet (diakses tanggal 13 September 2016)

51 Ibid.,

52 Inilah 15 Bukti Kekejaman Kelompok Abu Sayyaf, "Tidak Segan Penggal Kepala Sandera”,didapat dari: http:// kaltim.tribunnews.com/2016/04/08/ inilah-bukti-sadisme-kelompok-abusayyaf-tidak-segan-penggal-kepalasandera? page $=4$, Internet (diakses tanggal 05 Maret 2017) 
Selatan. ${ }^{53}$ Oleh karena warga $\mathrm{Ne}$ garanya yang masih di sandera $\mathrm{Abu}$ Sayyaf Group, maka dilanjutkan dengan program Balikatan Exercise 2002-1 (Program Balikatan 02-1). ${ }^{54}$ Program tersebut di khususkan untuk memberantas Abu Sayyaf Group sebagai inisiatif peningkatan kerjasama militer pemerintah Amerika Serikat dan pemerintah Filipina, yaitu:

\section{Program Balikatan Exercise 2002-1}

Hasil pertemuan antara Presiden Gloria Macapagal Arroyo yang bertemu langsung dengan Presiden George Walker Bush pada tanggal 20 November 2001. Presiden Gloria Macapagal Arroyo mengucapkan simpatinya terkait Tragedi 9/11 dan menindaklanjuti dukungan dengan pembahasan tentang konseptualisasikan Balikatan Exercise 2002-01 atau program Balikatan 02-1.

Dalam pertemuan itu, Amerika Serikat menawarkan bantuan militer secara langsung kepada pemerintah Filipina untuk menekan Abu Sayyaf

\footnotetext{
53 Jejak Berdarah Penyanderaan Kelompok Abu Sayyaf, didapat dari:http://news. detik.com/berita/3176560/jejakberdarah-penyanderaan- kelompokabu-sayyaf, Internet (diakses tanggal 28 Agustus 2016)

54 Ibid.,
}

Group..$^{55}$ Presiden Gloria Macapagal Arroyo menolak tawaran tersebut dan sebagai gantinya meminta peralatan militer baru dan pelatihan terhadap AFP untuk meningkatkan kemampuan dalam memberantas bu Sayyaf Group..$^{56}$ Kedua presiden tersebut menyetujui rencana terpadu untuk menyediakan paket pelatihan yang kuat bagi AFP, pengiriman peralatan yang dibutuhkan untuk meningkatkan mobilitas bagi militer Filipina, dan penciptaan konsultasi bilateral mengenai mekanisme pertahanan baru.

Dibandingkan dengan pelaksanaan program Balikatan sebelumnya, program Balikatan 02-1 dianggap lebih khusus dalam hal tujuan, sasaran dan kegiatan. Tujuan, sasaran dan kegiatan program Balikatan sebelumnya yang terfokus pada latihan interoperabilitas dalam menghadapi ancaman dari luar, sedangkan pada program Balikatan 02-1, di samping latihan interoperabilitas, Amerika Serikat juga terlibat peran sebagai penasehat bagi Filipina dalam memerangi Abu Sayyaf Group di Filipina Selatan.

\footnotetext{
Eric C. Ramos, hal. 51

56 Ibid.,
} 
Gambar 3: Operation Balikatan 02-1, 2002 In Zamboanga,Philippines

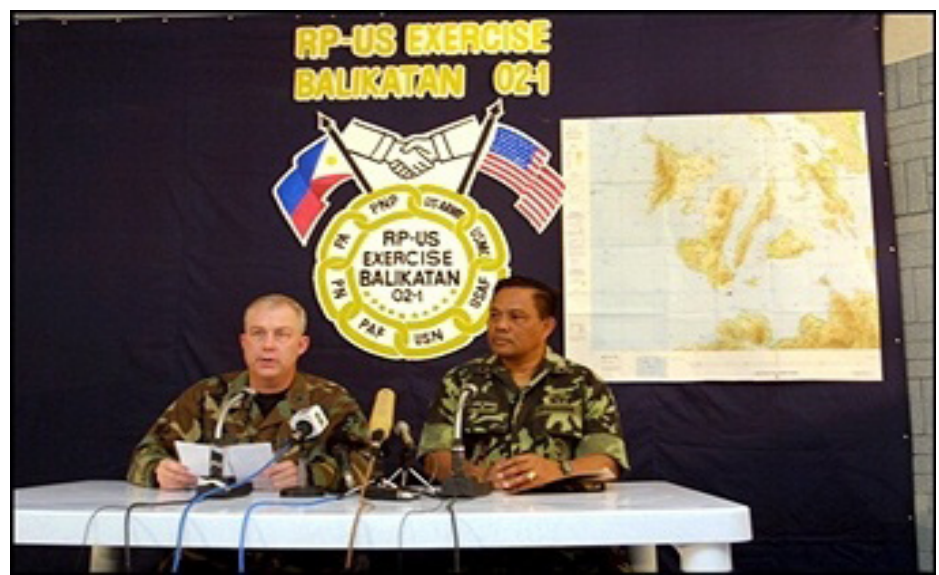

Sumber: www.gettyimages.com/license/109133383

Gambar: Internet (diakses tanggal 10 Februari 2017)

Program Balikatan 02-1 dilaksanakan di Mindanao, tepatnya di Pulau Basilan, tempat dimana $\mathrm{Abu}$ Sayyaf Group beroperasi di Filipina Selatan.

\section{Pelaksanaan Balikatan Exer- cise 2002-1}

Dalam memulai pelaksanaan, pasukan Amerika Serikat yang ditempatkan di Mindanao ditetapkan sebagai Joint Task Force 510 (JTF 510), dipimpin oleh Jenderal Donald Wurster dari United States Air Force (USAF), Komandan dari Special Operations Command Pacific (SOCPAC). JTF 510 menggunakan model counter-insurgency (COIN) yang dirancang untuk memutuskan

$57 \quad$ Ibid., dukungan masyarakat terhadap Abu Sayyaf Group, memperkuat respon pemerintah dan militer untuk mengatasi terorisme, serta meningkatkan kepatuhan masyarakat terhadap legitimasi pemerintaha Filipina. ${ }^{58}$ JTF 510 melaksanakan 3 (tiga) Lines of Operation (LOO), yaitu membangun kemampuan AFP, fokus dalam Civil Military Operation (CMO), dan Operasi Informasi (Information Operations) diantaranya: ${ }^{59}$

\section{a). Membangun Kemampuan AFP}

Penugasan JTF 510 dalam membangun kemampuan dan

$\begin{array}{ll}58 & \text { Ibid., } \\ 59 & \text { Ibid., }\end{array}$


legitimasi AFP untuk menciptakan lingkungan yang aman dan stabil serta melindungi masyarakat dengan cara menanggulangi $\mathrm{Abu}$ Sayyaf Group di Pulau Basilan. JTF-510 menetapkan prioritas utamanya adalah meningkatkan kepatuhan masyarakat terhadap legitimasi pemerintah Filipina melalui penggunaan model COIN, dan untuk keberhasilan tujuan ini, JTF-510 menempatkan AFP untuk mengamankan masyarakat dari ancaman Abu Sayyaf Group.

\section{b). Civil Military Operation (CMO)}

Pada awal pelaksanaan program Balikatan 02-1, banyak masyarakat di Pulau Basilan yang merasa tidak puas dan sebagian besar dari mereka merasa diabaikan oleh pemerintah Filipina. Abu SayyafGroup juga kerap menggunakan taktik intimidasi untuk mempengaruhi masyarakat agar tidak mempercayai AFP. Dalam rangka untuk memulihkan kepercayaan masyarakat terhadap AFP dan pemerintah Filipina, selain itu, JTF 510 juga mengembangkan program Civil Military Operation (CMO) yang bertujuan untuk memutuskan dukungan masyarakat kepada Abu Sayyaf Group melalui penyediakan pelayanan bagi masyarakat.

\section{c). Operasi Informasi}

JTF 510 melakukan Operasi Informasi dengan pemerintah Filipina dan Kedubes Amerika Serikat di Filipina untuk menekan keberhasilan dalam operasional dan membangun dukungan bagi pemerintah Filipina. Operasi ini kemungkinan adalah bagian yang paling sulit dari pelaksanaan program Balikitan 02-1. Masyarakat dan media di Filipina sangat curiga terhadap setiap operasi militer asing di negara mereka. Meskipun terdapat halangan dari masyarakat dan media Filipina, JTF-510 mampu mencapai beberapa keuntungan yang nyata. JTF 510 berhasil menggunakan media cetak, lisan dan pesan teks yang berkontribusi pada operasi taktis dan membangun legitimasi program Balikitan 02-1. Dari ketiga Lines of Operation ini telah membentuk persepsi yang baik maupun positif terhadap AFP dan pasukan Amerika Sserikat, sementara dukungan terhadap Abu Sayyaf Group menurun pada masyarakat. ${ }^{60}$

60 Major Daniel D. Mitchell and Major Michael D. Nelson, Accomplishing American Strategic Goals in the Middle East Through Persistent Special Operations, Naval Postgraduate School, hal. 39, 2011 


\section{Kesimpulan}

Latihan gabungan militer pertama pada Program Balikatan Exercise 2001 antara Amerika Serikat dan Filipina pada maret tahun 2001 dengan pasukan Light Reaction Company (LRC), memang tidak memberi efek terhadap $\mathrm{Abu}$ Sayyaf Group sebelum Tragedi 9/11. Namun pasca-Tragedi 9/11, Amerika Serikat serius menjalin kerjasama dengan Filipina dalam Program Balikatan Exercise 20021 untuk memberantas Abu Sayyaf Group. Hasilnya cukup di luar dugaan. Pertama, kegagalan dalam upaya penyelamatan terhadap sandera yang mengakibatkan tewasnya dua sandera dan melukai sandera lainnya. Sandera Martin Burnham dan seorang perawat warga negara Filipina bernama Ediborah Yap tewas sedangkan istri Martin Burnham, Gracia Burnham, selamat dan dilarikan ke rumah sakit setelah upaya penyelamatan oleh Angkatan Bersenjata Filipina (AFP). Kedua, Program ini juga gagal untuk menghilangkan $\mathrm{Abu}$ Sayyaf Group secara keseluruhan.

Adapun keberhasilan dari program ini yaitu menangkap dan membunuh salah satu pimpinan militer Abu Sayyaf Group faksi Basilan yaitu Abu Sabaya pada bulan Juni 2002 di Pantai Sibuco, kota Zamboanga Del Norte. Program Balikatan Exercise 20021 dilaporkan secara signifikan mengurangi kekuatan Abu Sayyaf Group di Pulau Basilan. Pada tahun 2000, Abu Sayyaf Group memiliki kekuatan dengan jumlah anggota yang aktif mencapai 1270 orang, dan pasca Program Balikatan Exercise 2002-1 berakhir pada bulan Juli tahun 2002, kekuatan Abu Sayyaf Group berkurang menjadi 460 anggota yang masih aktif di Pulau Basilan. Meskipun gagal untuk menghilangkan ancaman Abu Sayyaf Group, setidaknya latihan militer gabungan mengalami kesuksesan besar dalam meningkatkan kemampuan tempur dan taktik manuver AFP, serta meningkatkan Sistem Pertahanan Teritorial Terpadu atau Integrated Territorial Defense System pada AFP. Ini terbukti ketika AFP berhasil menetralisir Abu Sayyaf Group dan meminimalkan kemampuan kelompok tersebut untuk melakukan kegiatan teroris di Pulau Basilan. Namun, Abu Sayyaf Group masih bisa memindahkan pusat operasinya ke Pulau Jolo. Operasi AFP mengalami peningkatan sebagai hasil dari bantuan pelatihan Amerika Serikat dalam penyediaan peralatan modern, dan bantuan dalam perencanaan operasi. 
Keuntungan terbesar dari pelaksanaan Program Balikatan Exercise 2002-1 dapat dilihat lebih sebagai keuntungan di bidang politik daripadamiliter. Program Balikatan Exercise 2002-1 memperkuat dukungan publik dan politik domestik pada kerjasama Amerika Serikat dan Filipina yang dilengkapi program pemerintah Filipina dalam reformasi sosial dan pengentasan kemiskinan di Pulau Basilan. Masyarakat Pulau Basilan sangat menghargai bantuan ekonomi dan kemanusiaan yang disertai latihan militer gabungan. Program tersebut mendorong ekonomi di Pulau Basilan melalui pekerjaan dari perusahaan lokal milik warga negara Amerika Serikat untuk jasa seperti laundry (binatu) dan katering makanan.

Dari sisi Filipina, bantuan militer dari Amerika Serikat memberikan manfaat bagi Filipina terhadap peningkatan kemampuan AFP dalam menangani pemberontakan Abu Sayyaf Group. Kegiatan-kegiatan yang dilaksanakan dalam Program Balikatan Exercise 2002-1 efektif dalam mengatasi ancaman Abu Sayyaf Group di Pulau Basilan yang merupakan pusat operasi Abu Sayyaf Group. Sebaliknya, dari perspektif Amerika Serikat, perang melawan terorisme di Filipina
Selatan bisa dilaksanakan tanpa melibatkan pasukannya dalam pertempuran langsung partisipasi Amerika Serikat yang terbatas pada misi penasehat AFP maupun melaksanakan aksi kemanusiaan dan program kemasyarakatan di Pulau Basilan. Program Balikatan Exercise 2002-1 dapat disebut sebagai contoh pelatihan penanggulangan teroris dan misi bantuan dalam skala kecil yang sukses dengan mengkombinasikan berbagai instrumen politik, informasi, urusan sipil, ekonomi, kesehatan, dan sebagainya. dengan instrumen militer untuk melaksanakan kampanye dalam melawan teroris.

\section{Daftar Pustaka}

Buku:

Abuza Zachary, "Balik Terorism: The Retrun of Abu Sayyaf”, Carlisle: Strategic Studies Institute, hal 2, 2005.

Hasbullah Moeflich, "Asia Tenggara konsentrasi Baru Kebangkitan Islam", Fokusmedia, hal. 242, Bandung 2003.

Major Daniel D. Mitchell and Major Michael D. Nelson, Accomplishing American Strategic Goals in the Middle East Through Persistent Special Operations, Naval Postgraduate School, hal. 39, 2011. 
Pujayanti Adirini, "Kebijakan Luar Negeri Pemerintahan Bush Terhadap Terorisme Internasionala". dalam Poltak Pargi Nainggilan, Terorisme, Human Security, Keamanan Internasional dan Tata Dunia Pasca Perang Dingin, Terorisme dan Tata Dunia Baru, Jakarta: Pusat Pengkajian dan Pelayanan Infomasi Sekretariat Jenderal Dewan Perwakilan Rakyat Republik Indonesia, hal.161 2002.

Purwadarminta W.J.S., Kamus Umum Bahasa Indonesia, Balai Pustaka, hal. 492, Jakarta 1985. Sholahuddin, "NII sampai JI, Salafy Jihadisme di Indonesia", Komunitas Bambu, hal. 25, Jakarta 2011.

Vermonte, Phillips, Regional

Networking and coordination Againts International Terrorism: An Indonesia Perspective. The 13th Meeting of CSCAP Working Group Meeting on Transnational Crime, Manila 27-28 Juni 2003.

\section{Jurnal:}

Briscoe, C.H. "Balikatan exercise spearheaded ARSOF operations in the Philippines." Special Warfare, September. 2004.
Dr. Adnan Khalil Basha, "Largest Islamic Relief Organization Maligned," Letter to the Editor, Philippine Daily Inquirer, August 2000, p. 18; Christine Herrera, "Gemma Linked to Bin Laden Group Funding Abu Sayyaf Group, MILF,' Philippine Daily Inquirer, August 10, 2000. Robert J. Art, "A Grand Strategy for America", Cornell University Press, Ithaca, 2003.

Shedon W. Simon, "Southeast Asia and The War on Terrorism", Dalam Managing Security Challenges in Southeast Asia, NBR Analysis: Vol.13, 4 July 2002 (The National Bureau of Asian Research: Washington D.C., 2002).

The United States of America, "The National Security Strategy". 2002.

\section{Situs Internet dan MediaMassa:}

A National Security Strategy 1999, didapat dari: https://clinton4. nara.gov/media/pdf/nssr-1299. pdf, Internet [diakses tanggal 18 September 2016].

Abu Sayyaf Group (Philippines, Islamist separatists), didapat dari: http://www. cfrorg/philippines/abusayyafgroup-philippinesislamist-separatists/p9235, 
Internet[diakses tanggal 27 Agustus 2016].

Amerika Serikat Dan Filipina

Tingkatkan Kerjasama

Antiterorisme, didapat dari: http://indonesian.cri. cn/201/2009/07/31/1s99872.

htm, Internet [diakses tanggal 01 September 2016].

Henry Loedji, Filipina Modernisasi Senjata, didapat dari: http:// ramalanintelijen.net/pasukankomando-filipina-balasmenyerang-abu-sayyafmengerahkan-5-batalyon, Internet [diakses tanggal 14 September 2016].

John Roberts, "US Training exercise in the Philippines sets stage for Broader military operations", 15 Maret 2002. Kebijakan AS Dalam Mengatasi Terorisme, didapat dari: http://astiol.com/ terorism/6-global-terorism/22kebijakan-amerika-serikatdalam-mengatasi-terorisme. html, Internet [diakses tanggal 04 September 2016].

Soliman M. Santos, etc, "Primed and Purposeful Armed Groups and Human Security Efforts In The Philippines", Chapter 20, "AlHarakatul Al-Islamiyya, Abu Sayyaf Group (ASG)", SouthSouth Network for Non-State
Armed Group Engagement and the Small Arms Survey, 2010,http://www.isn.ethz.ch/ Digital-Library/Publications/ Detail/? ots591=0c54e3b31 e 9 c - b e 1 e - 2 c 24 a 6 a 8 c $7060233 \& 1 \mathrm{ng}$ $=$ en $\& i d=115743$, Internet [diakses tanggal 30 Agustus 2016].

Steven Mufson, "U.S. to Aid Philippines' Terrorism War", Washington Post, 21 November 2001, www.elib.unikom.ac.id/ download.php?id=143138.pdf, Internet [diakses tanggal 03 September 2016].

The National Security Strategy USA 2002, didapat dari http:// www.state.gov/documents/ organization/63562.pdf, Internet [diakses tanggal 13 September 2016].

The Phillipines and Terrorism, didapat dari: http://www. adl.org/terror/tu/tu_0404_ philippines.asp, Internet [diakses tanggal 14 September 2016].

Quadrennial Defense Report USA 2001, didapat dari: http://www. gao.gov/new.items/d0313.pdf, Internet [diakses tanggal 17 September 2016]. 
Washington File: "US, Philippines Allied in the War Against Terrorism", didapat dari: http://wfile.ait.org.tw/ wfarchive/2001/011120/epf214. htm, Internet [diakses tanggal 03 September 2016]. 